\title{
Genetic Gain Over 30 Years of Spring Wheat Breeding in Brazil
}

\author{
Leomar Guilherme Woyann, Andrei Daniel Zdziarski, Rodrigo Zanella, Ana Claudia Rosa, \\ Ricardo Lima de Castro, Eduardo Caierão, Marcelo De Carli Toigo, Lindolfo Storck, Jixiang Wu, \\ and Giovani Benin^
}

\begin{abstract}
Wheat (Triticum aestivum L.) is one of the most important crops in the world. Brazil is one of the largest importers of this cereal, and wheat breeding programs are attempting to increase productivity and reduce external dependence. The objectives of this study were to quantify the spring wheat genetic gain in Brazil between 1984 and 2014 using data from multienvironment trials, and to verify if the genetic gain stagnated after the 2000s. This study used a highly unbalanced dataset containing grain yield (GY) data from 187 spring wheat trials that were performed at 25 locations between 2002 and 2015. In total, 126 cultivars, released between 1985 and 2014, were evaluated over 14 crop seasons. The cultivar evaluation indicated that there was a genetic gain in GY of $33.9 \mathrm{~kg}$ $\mathrm{ha}^{-1} \mathrm{yr}^{-1}\left(r^{2}=0.53, P<0.01\right)$, which represents an increase of $1.28 \% \mathrm{yr}^{-1}$. The dataset showed a linear regression for the genetic gain and indicates that wheat genetic gain has not stagnated in Brazil after the 2000s.
\end{abstract}

L.G. Woyann, A.D. Zdziarski, R. Zanella, A.C. Rosa, L. Storck, and G. Benin, Federal Univ. of Technology-Paraná (UTFPR), Campus Pato Branco, Via do Conhecimento, Km 1, CEP 85503-390, Pato Branco, Paraná, Brazil; R.L. de Castro and E. Caierão, Embrapa Trigo, Rodovia BR 285, km 294. Caixa Postal 3081, CEP 99050-970, Passo Fundo, Rio Grande do Sul, Brazil; M.D.C. Toigo, Fundação Estadual de Pesquisa Agropecuária (FEPAGRO), Centro de Pesquisa de Vacaria-DDPA/SEAPI, Rodovia BR 285, km 126, Caixa Postal 20, CEP: 95000-000, Vacaria, Rio Grande do Sul, Brazil; J. Wu, Dep. of Agronomy, Horticulture \& Plant Science, South Dakota State Univ., SNP 244D, Box 2140C Brookings, SD 57007. Received 27 Feb. 2019. Accepted 30 May 2019. `Corresponding author (benin@utfpr.edu.br). Assigned to Associate Editor Esten Mason.

Abbreviations: GY, grain yield; MET, multienvironment trial; NUE, nitrogen use efficiency.

A NNUAL wheat (Triticum aestivum L.) production in Brazil is $\sim 6 \mathrm{Tg}$ (CONAB, 2017). This production is insufficient to meet the Brazilian demand and makes Brazil one of the main importers of wheat. The southern region, formed by the states of Rio Grande do Sul, Santa Catarina, and Paraná, is the main wheat producing region and accounts for $\sim 90 \%$ of the wheat production in Brazil (CONAB, 2017).

Estimates indicate that the world population will reach 9 billion by 2050 (Godfray et al., 2010). Therefore, food production will need to double to meet demand and to avoid a generalized increase in food prices (Tweeten and Thompson, 2008). To reach this goal, the main agricultural crops (i.e., maize [Zea mays L.], wheat, rice [Oryza sativa L.], and soybean [Glycine max (L.) Merr.; Ray et al., 2013) will have to show a $2.4 \%$ annual increase in production. This can be achieved by increasing productivity or the land area devoted to cultivation. However, increasing the cultivated area is obstructed by challenges, such as the lack of new arable areas, and the loss of productive areas due to degradation and climate change (Gibbs et al., 2010; Lal, 2015).

Published in Crop Sci. 59:1-10 (2019).

doi: 10.2135/cropsci2019.02.0136

(C) 2019 The Author(s). Re-use requires permission from the publisher. 
Increases in productivity are the result of two major components: environmental improvement and genetic gain (Xiao and Tao, 2014). Environmental improvement (including agronomic practices) leads to a better environment, in which the crop is more likely to reach its productive potential. Environment improvement includes providing adequate fertility, an adequate water supply, and eliminating other biotic and abiotic constraint factors (Bell et al., 1995; Laidig et al., 2014). Genetic gain can be defined as the increase in performance that is achieved annually through genetic improvement after the environmental effect is excluded (Xu et al., 2017). This means that a new genetically improved cultivar should provide higher yields than older ones when grown under the same environmental conditions.

Wheat crop genetic gains vary among producing regions. Previous comprehensive studies (with a large number of genotypes and sites) showed that there was an annual genetic gain of $0.8 \%$ in the United States between 1980 and 2010 (Graybosch et al., 2014), 1.29\% in China from 1950 to 2015 (Qin et al., 2015), 1.17\% in Argentina from 1940 to 1999 (Lo Valvo et al., 2018), and 0.88\% in Spain for cultivars released between 1930 and 2000 (Sanchez-Garcia et al., 2013). Morgounov et al. (2010) also reported an annual genetic gain of $0.7 \% \mathrm{yr}^{-1}$ over $100 \mathrm{yr}$ of wheat genetic improvement in western Siberia, and Aisawi et al. (2015) reported an annual genetic gain of $0.59 \%\left(30 \mathrm{~kg} \mathrm{ha}^{-1} \mathrm{yr}^{-1}\right)$ after analyzing the data from International Maize and Wheat Improvement Center (CIMMYT) cultivars released between 1966 and 2009. Ray et al. (2013) reported a 0.9\% of global annual genetic gain for wheat crops. However, these improvements are considerably smaller than those needed to meet the demand for food in the mid-21st century.

Stagnation of genetic gains obtained through breeding has been reported for the main crops, such as rice (Peng et al., 1999, 2010; Cassman et al., 2003; Li et al., 2016), maize (Hawkins et al., 2013; Li et al., 2016), and wheat. In wheat, a trend towards the stagnation of genetic gains has been reported in several producing regions. Lo Valvo et al. (2018) indicated that Argentine cultivars released after 1999 achieved a genetic gain of only $14 \mathrm{~kg} \mathrm{ha}^{-1} \mathrm{yr}^{-1}$ $\left(0.18 \% \mathrm{yr}^{-1}\right)$. A genetic gain plateau was also observed by Graybosch and Peterson (2010), who reported that gains stagnated in the Great Plains region of the United States between 1984 and 2008. Furthermore, Matus et al. (2012) showed that in Chile, genetic gains stagnated in cultivars released between 1990 and 2000, and Brisson et al. (2010) reported that the genetic gain in France was counterbalanced after the 1990s by climate changes, especially heat stress. In this context, it is of fundamental importance to evaluate genetic progress so that new processes and breeding techniques can be adopted that anticipate future demands, protect and continue income gains, and ensure food security over the next decades.
In Brazil, some studies have evaluated the genetic gain in wheat. These studies used different methodologies to analyze the genetic improvement, covered different periods of wheat improvement, focused on different regions, and produced results that were significantly different. Follmann et al. (2017) observed an average genetic gain of $2.86 \% \mathrm{yr}^{-1}$ using data from cultivars that were released after 1980 and evaluated for $12 \mathrm{yr}$ (2002 to 2013). Beche et al. (2014b) used data from cultivars that had been released from the beginning of wheat improvement in Brazil (1940) until 2009, and they observed genetic gains of $29 \mathrm{~kg} \mathrm{ha}^{-1} \mathrm{yr}^{-1}(0.92 \%$ $\left.\mathrm{yr}^{-1}\right)$. However, they did not find any significant genetic gains when cultivars released between 1999 and 2009 were evaluated. Other studies have reported intermediate values between these extremes. For example, Rodrigues et al. (2007) reported gains of $44.9 \mathrm{~kg} \mathrm{ha}^{-1} \mathrm{yr}^{-1}\left(1.54 \% \mathrm{yr}^{-1}\right)$ for cultivars released in the southern region of Brazil between 1940 and 1992, whereas Cargnin et al. (2009) obtained values of $37 \mathrm{~kg} \mathrm{ha}^{-1} \mathrm{yr}^{-1}$ for cultivars released in the central region of Brazil between 1976 and 2005.

Previous studies that evaluated genetic wheat gains in Brazil used cultivars released across different decades in trials with one or a few evaluation locations (Rodrigues et al., 2007; Cargnin et al., 2009; Beche et al., 2014b). In contrast, Follmann et al. (2017) used data from multienvironment trials (METs) and performed a meta-analysis (Breseghello et al., 2011). All these studies used the "cultivar substitution" methodology proposed in the influential study by Vencovsky et al. (1988), based on generalized minimum squares. The genetic gain is estimated every 2 yr by linear regression, which means that the genetic gain is obtained from the gross difference between 2 yr minus the environmental difference (Vencovsky et al., 1988). Subsequently, the genetic gain for the whole period is obtained from the general average of the biennial values.

Studies using MET data are generally unbalanced due to cultivar substitution and breeding processes (Piepho and Möhring, 2005; So and Edwards, 2011; Yan, 2015). This configuration of data makes mixed models more robust than fixed models (Piepho and Möhring, 2006; Burgueño et al., 2011; So and Edwards, 2011). An estimation of the variance components in mixed models that use MET data can be obtained using the restricted maximum likelihood method (REML) (Piepho and Möhring, 2006; So and Edwards, 2011). Another option is the minimum norm quadratic unbiased estimation (MINQUE) (Rao, 1971), which when integrated with the jackknife method has lower computational requirements than other methods (Wu et al., 2010). The evaluation of MET data using linear mixed models produces more reliable estimates of genetic gain (de la Vega et al., 2007). The objectives of this study were to quantify the genetic gain for spring wheat in Brazil between 1985 and 2014 using METs, and to verify genetic gain stagnation in Brazil after the 2000s. 


\section{MATERIALS AND METHODS \\ Study Region}

The trials were conducted in the southern region of Brazil between 2002 and 2015. Twenty-five trial locations were distributed among the three states within this region. There were 21 in Rio Grande do Sul, three in Santa Catarina, and one in Paraná (Table 1). These three states account for $\sim 90 \%$ of Brazilian wheat production (CONAB, 2017). In some years, the Cruz Alta and Passo Fundo locations contained more than one trial because these locations represent two of the main wheat producing regions of the country, and several wheat breeding companies are located there. In this study, the position of the trials varied at the same location in each year. However, in each year, the trial was installed in an area that represents the location. A description of the test locations, geographic coordinates (latitude, longitude, and altitude), number of trials, and the number of years in which trials were conducted at a given location are shown in Table 1.

\section{Dataset and Evaluated Cultivars}

A dataset containing 187 spring wheat trials was used to estimate the genetic gain for grain yield (GY). In total, 126 Brazilian spring wheat cultivars, released between 1985 and 2014, were evaluated between 2002 and 2015 (Table 2). Different cultivars were used each year because new cultivars were released, and old cultivars were excluded from the trials. The number of entries evaluated each year was limited to 30 to 35 cultivars. The cultivars evaluated in the trials for a given year met two main criteria: (i) cultivars had been released up to $2 \mathrm{yr}$ prior to the implementation of the trials, and (ii) the trials included previously released cultivars that had the greatest seed market shares in the previous crop season.

All cultivars evaluated during the $14 \mathrm{yr}$ of trials, with their respective years of release, breeding company, and number of years in the trials, are shown in Supplemental Table S1. The same cultivars were grown at all locations in each year. Across years, genotypes were substituted with newly released cultivars, and no single cultivar was grown throughout the 14 growing seasons. This resulted in highly unbalanced datasets (Table 2). For example, 34 cultivars were evaluated in the 2002 trials, but only 20 of these 34 cultivars were present in the 2003 trials and 11 new cultivars entered the trials. Furthermore, 30 cultivars were evaluated in 2010, but only one of those cultivars was trialed in 2002. The number of cultivars evaluated every year varied between 29 and 37, and the number of trials varied between 5 (2002) and 23 (2014).

Table 1. Locations used in cultivar evaluation trials from 2002 to 2015, geographic coordinates (latitude, longitude, and altitude), total number of trials in a location, and years where trials were conducted in a location.

\begin{tabular}{|c|c|c|c|c|c|}
\hline Location & Latitude & Long & Altitude & $\begin{array}{c}\text { No. of trials } \\
\text { (total) }\end{array}$ & Years of evaluation \\
\hline & & & $\mathrm{m}$ & & \\
\hline Abelardo Luz, Santa Catarina & $26^{\circ} 33^{\prime} \mathrm{S}$ & $52^{\circ} 19^{\prime} \mathrm{W}$ & 778 & 5 & 2009-2012, 2014 \\
\hline Augusto Pestana, Rio Grande do Sul & $28^{\circ} 31^{\prime} \mathrm{S}$ & $53^{\circ} 59^{\prime} \mathrm{W}$ & 367 & 5 & $2011-2015$ \\
\hline Cachoeira do Sul, Rio Grande do Sul & $30^{\circ} 02^{\prime} \mathrm{S}$ & $52^{\circ} 53^{\prime} \mathrm{W}$ & 63 & 2 & 2002, 2006 \\
\hline Campos Novos, Santa Catarina & $27^{\circ} 24^{\prime} \mathrm{S}$ & $51^{\circ} 13^{\prime} \mathrm{W}$ & 934 & 6 & 2009-2012, 2014-2015 \\
\hline Casca, Rio Grande do Sul & $28^{\circ} 33^{\prime} \mathrm{S}$ & $51^{\circ} 58^{\prime} \mathrm{W}$ & 615 & 1 & 2014 \\
\hline Caxias do Sul, Rio Grande do Sul & $29^{\circ} 10^{\prime} \mathrm{S}$ & $51^{\circ} 10^{\prime} \mathrm{W}$ & 785 & 2 & 2013-2014 \\
\hline Chapecó, Santa Catarina & $27^{\circ} 06^{\prime} \mathrm{S}$ & $52^{\circ} 36^{\prime} \mathrm{W}$ & 667 & 6 & 2009-2012, 2014-2015 \\
\hline Coxilha, Rio Grande do Sul & $28^{\circ} 07^{\prime} \mathrm{S}$ & $52^{\circ} 17^{\prime} \mathrm{W}$ & 699 & 13 & 2002-2011, 2013-2015 \\
\hline Cruz Alta†, Rio Grande do Sul & $28^{\circ} 38^{\prime} \mathrm{S}$ & $53^{\circ} 36^{\prime} \mathrm{W}$ & 477 & 21 & $\begin{array}{c}\text { 2002-2003, } 2004 \text { (2)ł, 2005-2010, 2011- } 2012 \text { (2), } \\
\text { 2013-2014 (3), } 2015\end{array}$ \\
\hline Eldorado do Sul, Rio Grande do Sul & $29^{\circ} 59^{\prime} \mathrm{S}$ & $51^{\circ} 18^{\prime} \mathrm{W}$ & 24 & 9 & 2003-2006, 2008, 2012-2015 \\
\hline Encruzilhada do Sul, Rio Grande do Sul & $30^{\circ} 32^{\prime} \mathrm{S}$ & $52^{\circ} 31^{\prime} \mathrm{W}$ & 426 & 1 & 2004 \\
\hline Giruá, Rio Grande do Sul & $28^{\circ} 01^{\prime} \mathrm{S}$ & $54^{\circ} 21^{\prime} \mathrm{W}$ & 431 & 2 & 2004-2005 \\
\hline Guarapuava, Paraná & $25^{\circ} 23^{\prime} \mathrm{S}$ & $51^{\circ} 27^{\prime} \mathrm{W}$ & 1116 & 7 & 2007-2009, 2011, 2012, 2014, 2015 \\
\hline ljuí, Rio Grande do Sul & $28^{\circ} 23^{\prime} \mathrm{S}$ & $53^{\circ} 54^{\prime} \mathrm{W}$ & 323 & 6 & 2006-2008, 2010, 2014-2015 \\
\hline Independência, Rio Grande do Sul & $27^{\circ} 49^{\prime} \mathrm{S}$ & $54^{\circ} 11^{\prime} \mathrm{W}$ & 382 & 2 & 2012-2013 \\
\hline Júlio de Castilhos, Rio Grande do Sul & $29^{\circ} 13^{\prime} \mathrm{S}$ & $53^{\circ} 40^{\prime} \mathrm{W}$ & 528 & 8 & 2006-2012, 2014 \\
\hline Não-Me-Toque, Rio Grande do Sul & $28^{\circ} 27^{\prime} \mathrm{S}$ & $52^{\circ} 49^{\prime} W$ & 520 & 9 & 2005, 2007-2014 \\
\hline Passo Fundo*, Rio Grande do Sul & $28^{\circ} 15^{\prime} \mathrm{S}$ & $52^{\circ} 24^{\prime} \mathrm{W}$ & 679 & 22 & 2004-2005 (2), 2006, 2007-2014 (2), 2015 \\
\hline Pelotas, Rio Grande do Sul & $31^{\circ} 46^{\prime} \mathrm{S}$ & $52^{\circ} 20^{\prime} \mathrm{W}$ & 14 & 4 & 2004-2006, 2009 \\
\hline São Luiz Gonzaga, Rio Grande do Sul & $28^{\circ} 24^{\prime} \mathrm{S}$ & $54^{\circ} 57^{\prime} \mathrm{W}$ & 263 & 11 & 2002-2004, 2007-2012, 2014-2015 \\
\hline Santo Augusto, Rio Grande do Sul & $27^{\circ} 51^{\prime} \mathrm{S}$ & $53^{\circ} 46^{\prime} W$ & 532 & 10 & 2004-2010, 2013-2015 \\
\hline São Borja, Rio Grande do Sul & $28^{\circ} 39^{\prime} \mathrm{S}$ & $56^{\circ} 00^{\prime} \mathrm{W}$ & 81 & 10 & 2004-2006, 2009-2015 \\
\hline Sertão, Rio Grande do Sul & $27^{\circ} 58^{\prime} \mathrm{S}$ & $52^{\circ} 15^{\prime} \mathrm{W}$ & 743 & 6 & 2010-2015 \\
\hline Três de Maio, Rio Grande do Sul & $27^{\circ} 46^{\prime} \mathrm{S}$ & $54^{\circ} 14^{\prime} \mathrm{W}$ & 344 & 5 & 2009-2011, 2014-2015 \\
\hline Vacaria, Rio Grande do Sul & $28^{\circ} 0^{\prime} \mathrm{S}$ & $50^{\circ} 56^{\prime} \mathrm{W}$ & 961 & 14 & 2002-2015 \\
\hline
\end{tabular}

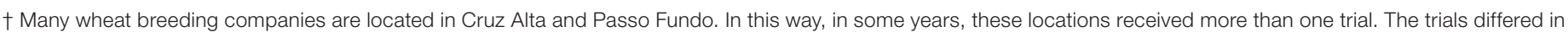

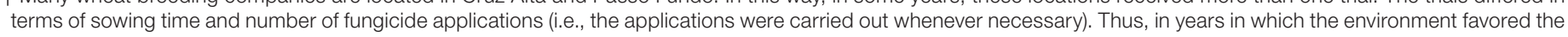
appearance of diseases, the number of applications was greater.

$\ddagger$ Values in parentheses indicate that more than one trial was conducted in this location in this year. 
Table 2. Number of Brazilian spring wheat cultivars common across years in the trial dataset (diagonal entries are numbers of cultivars for individual years), number of trials per year, and mean grain yield.

\begin{tabular}{|c|c|c|c|c|c|c|c|c|c|c|c|c|c|c|}
\hline Year & 2002 & 2003 & 2004 & 2005 & 2006 & 2007 & 2008 & 2009 & 2010 & 2011 & 2012 & 2013 & 2014 & 2015 \\
\hline 2002 & 34 & & & & & & & & & & & & & \\
\hline 2003 & 20 & 31 & & & & & & & & & & & & \\
\hline 2004 & 15 & 18 & 35 & & & & & & & & & & & \\
\hline 2005 & 11 & 14 & 30 & 37 & & & & & & & & & & \\
\hline 2006 & 7 & 10 & 22 & 28 & 33 & & & & & & & & & \\
\hline 2007 & 6 & 8 & 20 & 26 & 30 & 35 & & & & & & & & \\
\hline 2008 & 4 & 6 & 15 & 21 & 24 & 29 & 29 & & & & & & & \\
\hline 2009 & 4 & 4 & 12 & 18 & 22 & 24 & 23 & 35 & & & & & & \\
\hline 2010 & 1 & 1 & 5 & 8 & 12 & 14 & 13 & 25 & 30 & & & & & \\
\hline 2011 & 0 & 0 & 1 & 1 & 3 & 3 & 3 & 9 & 16 & 30 & & & & \\
\hline 2012 & 0 & 0 & 0 & 0 & 3 & 3 & 3 & 7 & 13 & 26 & 32 & & & \\
\hline 2013 & 0 & 0 & 0 & 0 & 2 & 2 & 2 & 7 & 9 & 18 & 25 & 30 & & \\
\hline 2014 & 0 & 0 & 0 & 0 & 1 & 1 & 1 & 5 & 8 & 14 & 18 & 22 & 30 & \\
\hline 2015 & 0 & 0 & 0 & 0 & 0 & 0 & 0 & 3 & 5 & 11 & 14 & 17 & 24 & 30 \\
\hline $\begin{array}{l}\text { No. of trials } \\
\text { per year }\end{array}$ & 5 & 5 & 13 & 11 & 11 & 11 & 12 & 16 & 16 & 17 & 17 & 15 & 23 & 15 \\
\hline $\begin{array}{l}\text { Mean grain } \\
\text { yield }\left(\mathrm{t} \mathrm{ha}^{-1}\right) \dagger\end{array}$ & 2.737 & 3.272 & 3.247 & 3.118 & 3.129 & 2.949 & 3.132 & 3.724 & 3.945 & 4.768 & 3.488 & 4.860 & 3.469 & 3.362 \\
\hline
\end{tabular}

† Across the entire dataset, average grain yield was $3.514 \mathrm{t} \mathrm{ha}^{-1}$

\section{Experimental Design and Plot Management}

Seed sowing occurred between 15 May and 15 June every year and followed the technical recommendations for each location. A randomized complete block design with three replications was used. The five-row plots were $5 \mathrm{~m}$ in length with an inter-row spacing of $0.20 \mathrm{~m}$, spanning a total plot area of $5 \mathrm{~m}^{2}$. Experimental plot seeders were used to sow the crops at a density of 330 plants $\mathrm{m}^{-2}$. The seeds were treated with imidacloprid insecticide at a dose of $100 \mathrm{~mL} 100 \mathrm{~kg}^{-1}$ seed. Fungicides were also applied. The fungicides were commercial products that contained triazoles and strobilurins. The number of applications varied from one to three, depending on disease incidence. Insecticides were also applied, and the number of insecticide applications and the active ingredient used varied according to the year and trial. Fertilization and other cultural practices were performed according to the technical information for the wheat crop. At harvest, grain moisture was corrected to 13\% and GY was measured in metric tons per hectare.

\section{Statistical Analysis}

The linear mixed model used the phenotypic observation $y_{i i m n}$ of cultivar $i$ in the year $j$, location $m$, and repetition $n$. The equation is as follows:

$$
\begin{aligned}
y_{i j m n}= & \mu+G_{i}+Y_{j}+L_{m}+(Y \times L)_{j m} \\
& +(Y \times L \times B)_{j m n}+B_{n(j m)}+e_{i j m n}
\end{aligned}
$$

where $\mu$ is the general mean, $G_{i}$ is the aleatory effect of the genotype, $Y_{j}$ is the year effect, $L_{m}$ is the location effect, $B_{n(j m)}$ is the effect of repetition $n$ nested on location $m$ in year $j, e_{i j m n}$ is the residual effect of genotype $i$ on repetition $n$ in year $j$ at location $m$. The analysis was performed by the Minque package (Wu, 2014) using the "lmm.jack" function.

The analysis of the genetic gain using the cultivar substitution methodology was performed according to Vencovsky et al.
(1988). The significance of the genetic gains for each biennium was tested according to Storck et al. (2005). A script in R was developed for this analysis (Supplemental File S2). Both analyses were performed using $\mathrm{R}$ platforms ( $\mathrm{R}$ Development Core Team, 2017) and graphical interface RStudio (RStudio Team, 2016). All figures were obtained using SigmaPlot 11 (Systat Software, 2008).

\section{RESULTS}

The variance components were significantly different $(P<$ $0.01)$ (Table 3). The largest estimated variance components were the year, location, and year $\times$ location interaction (i.e., environment) effects. The environmental interaction effect was responsible for $52 \%$ of the total variance. The simple effects of year and location both represented $11.7 \%$ of the total variance. Therefore, the effects related to the environment accounted for $>75 \%$ of the total variance. In contrast with the variance components for environmental effects, the cultivar variance component was low and only contributed $6 \%$ to the total variance.

The mixed models used to evaluate the 126 Brazilian spring wheat cultivars released between 1984 and 2014 indicated that there was a genetic gain (GY) of $33.9 \mathrm{~kg}$ $\mathrm{ha}^{-1} \mathrm{yr}^{-1}\left(r^{2}=0.53, P<0.01\right)$ (Fig. 1). This represents a genetic gain of $1.28 \% \mathrm{yr}^{-1}$.

The analysis of the dataset using the methodology proposed by Vencovsky et al. (1988) indicated that there was a genetic gain of $52.6 \mathrm{~kg} \mathrm{ha}^{-1} \mathrm{yr}^{-1}$ or an increase of $1.98 \% \mathrm{yr}^{-1}$ (Table 4). This method evaluates the genetic gain on a year-by-year basis, which means that extreme genetic gains can occur. For example, the 2003-2002 and 2014-2013 biennia recorded genetic gains of 206 and 136 $\mathrm{kg} \mathrm{ha}^{-1}$, respectively. In contrast, negative genetic gains occurred in the 2007-2006 and 2015-2014 biennia. 
Table 3. Estimation of components of variance, SE, the $2.5 \%$ lower limit $(2.5 \%$ LL) and $97.5 \%$ upper limit (97.5\% UL) of the confidence interval, and proportional variance components as a percentage (PVar).

\begin{tabular}{|c|c|c|c|c|c|}
\hline Factor & Variance & SE & $2.5 \% \mathrm{LL}$ & $97.5 \%$ UL & PVar† \\
\hline Year & $0.207^{\star \star}$ & 0.002 & 0.202 & 0.213 & $0.117^{\star *}$ \\
\hline Location & $0.208^{\star \star}$ & 0.003 & 0.197 & 0.218 & $0.117^{\star \star}$ \\
\hline Cultivar & $0.109^{\star *}$ & 0.003 & 0.097 & 0.120 & $0.061^{\star \star}$ \\
\hline Year $\times$ location & $0.926^{\star *}$ & 0.004 & 0.911 & 0.941 & $0.521^{\star *}$ \\
\hline Year $\times$ location $\times$ repetition & $0.016^{\star \star}$ & 0.001 & 0.014 & 0.018 & $0.009^{\star \star}$ \\
\hline Error & $0.310^{* *}$ & 0.002 & 0.304 & 0.316 & $0.174^{\star *}$ \\
\hline
\end{tabular}

** Significant at the 0.01 probability level.

†PVar was calculated dividing the variance estimated for each component by the total variance. The sum of all components is equal to 1 .

The GY increment for the period 2002 to 2014 was $86.2 \mathrm{~kg} \mathrm{ha}^{-1} \mathrm{yr}^{-1}$ when it was estimated by the mixed models (Fig. 2). This value represented environmental and agronomic improvements (soil, fertilizers, fungicides, sowing density, and sowing time), and the genetic gain itself, which was due to the development of more productive cultivars. The annual increment was $77.3 \mathrm{~kg} \mathrm{ha}^{-1} \mathrm{yr}^{-1}$ when calculated using the Vencovsky cultivar substitution method (data not shown).

\section{DISCUSSION}

\section{Use of Mixed Models to Assess the Wheat Genetic Gain Data from Multienvironment Trials}

In the ANOVA, the environmental effects contributed most to the estimated variance. The greater contribution of the environmental effects is possibly due to the large increase in the areas that include the locations used in the MET. These locations range from Pelotas in the extreme south of Rio Grande do Sul State to Guarapuava in Paraná State, with altitudes varying from $14 \mathrm{~m}$ to $1116 \mathrm{~m}$ asl (Table 1). Similar results for the variance components were reported by Lopez-Cruz et al. (2015) and Matei et al. (2017) in their wheat and soybean METs.

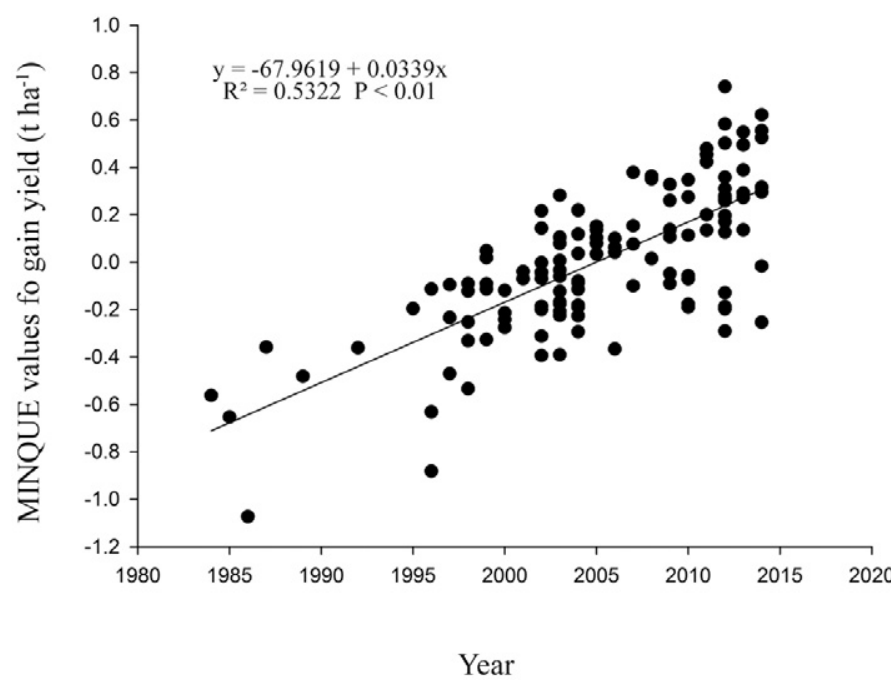

Fig. 1. Values predicted by minimum norm quadratic unbiased estimation (MINQUE) for the genetic gain for grain yield in 126 Brazilian spring wheat cultivars released between 1985 and 2014.
The genetic gain shown by the dataset analysis was within the range of results reported by other studies on wheat crops. Many studies that evaluated winter and spring wheat reported lower genetic gains (e.g., $0.59 \%$ by Aisawi et al., 2015, at CIMMYT; 0.7\% by Morgounov et al., 2010, in Siberia; 0.88\% by Sanchez-Garcia et al., 2013, in Spain; and 1\% by Wu et al., 2014, in China). The lower genetic gains in these studies may be due to high initial yields. Although there were larger increments in kilograms per hectare per year than those found in Brazil, the percentage gain was lower, because the yield in the initial years of the evaluated series was greater than that reported in Brazil. An example of this situation was the genetic gain obtained by Wu et al. (2014) of $66 \mathrm{~kg} \mathrm{ha}^{-1}$, which represents a gain of just $1 \% \mathrm{yr}^{-1}$. However, Matus et al. (2012) reported gains of $246 \mathrm{~kg} \mathrm{ha}^{-1} \mathrm{yr}^{-1}$ or $2.6 \%$ $\mathrm{yr}^{-1}$ in Chile, which were greater than those reported in this study. The average wheat GY in Chile was $4200 \mathrm{~kg}$ $\mathrm{ha}^{-1}$ between 1965 and 1975 but increased to $10,000 \mathrm{~kg}$ $\mathrm{ha}^{-1}$ between 1996 and 1998 (Matus et al., 2012). This yield increase explains the high genetic gain reported by these authors. In addition, the use of irrigation may have contributed to the large genetic gains in Chile.

\section{Analysis of Genetic Gain Using the Cultivar Substitution Method}

Many studies that evaluated genetic gains in wheat in Brazil used the Vencovsky cultivar substitution method (Rodrigues et al., 2007; Cargnin et al., 2009; Beche et al., 2014b; Follmann et al., 2017). The genetic gain obtained using this method was higher than that obtained from the linear mixed models $\left(52.6 \mathrm{~kg} \mathrm{ha}^{-1} \mathrm{yr}^{-1}\right.$ or an increase of $\left.1.98 \% \mathrm{yr}^{-1}\right)$. This value was similar to that obtained by Follmann et al. (2017), who reported a genetic gain of $61.36 \mathrm{~kg} \mathrm{ha}^{-1} \mathrm{yr}^{-1}$ or an increase of $2.86 \% \mathrm{yr}^{-1}$ using the same methodology. The highest genetic gain values may be related to the large environmental effect identified in the variance estimation and the presence of years with a high percentage of missing data. This methodology can be appropriate when a set of genotypes released in different years are tested at one or a few locations, or conducted in ideal conditions, which minimizes the environmental effects. However, with METs that have accentuated year 
Table 4. Mean grain yield of trials for evaluation years, number of cultivars ( $n$ ), mean square error (MSe), number of common cultivars between biennia ( $\mathrm{nc}$ ), rates of maintained ( $\mathrm{rm}$ ) and substituted ( $\mathrm{rs}$ ) cultivars, genetic gain, and significance of the hypothesis test (Ho: genetic gain $=0$, alpha\%) per biennia in multienvironment trials of spring wheat in Brazil according to the method of cultivar substitution proposed by Vencovsky et al. (1988).

\begin{tabular}{|c|c|c|c|c|c|c|c|c|c|c|}
\hline Year & $\begin{array}{l}\text { Mean grain } \\
\text { yield }\end{array}$ & $n$ & DFe† & MSe & Biennia & nc & $\mathrm{rm}$ & rs & $\begin{array}{l}\text { Genetic } \\
\text { gain }\end{array}$ & Alpha\% \\
\hline & t ha $^{-1}$ & & & & & & 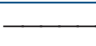 & 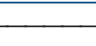 & tha $^{-1}$ & $\%$ \\
\hline 2002 & 2.737 & 34 & 330 & 0.071074 & 2003-2002 & 20 & 44.44 & 35.48 & 0.206127 & 0 \\
\hline 2003 & 3.272 & 31 & 300 & 0.061807 & 2004-2003 & 18 & 37.5 & 48.57 & 0.050457 & 0.002 \\
\hline 2004 & 3.2467 & 35 & 884 & 0.081781 & 2005-2004 & 30 & 71.43 & 18.92 & 0.113387 & 0 \\
\hline 2005 & 3.118 & 37 & 792 & 0.073569 & 2006-2005 & 28 & 66.67 & 15.15 & 0.021202 & 0.222 \\
\hline 2006 & 3.1292 & 33 & 640 & 0.20631 & 2007-2006 & 30 & 78.95 & 14.29 & -0.01775 & 99.913 \\
\hline 2007 & 2.9492 & 35 & 748 & 0.081969 & 2008-2007 & 29 & 82.86 & 0 & 0.032069 & 0 \\
\hline 2008 & 3.1324 & 29 & 672 & 0.129993 & 2009-2008 & 23 & 56.1 & 34.29 & 0.068623 & 0 \\
\hline 2009 & 3.7236 & 35 & 1088 & 0.145625 & 2010-2009 & 23 & 54.76 & 23.33 & 0.017105 & 2.054 \\
\hline 2010 & 3.9448 & 30 & 928 & 0.117342 & 2011-2010 & 16 & 36.36 & 46.67 & 0.001854 & 44.489 \\
\hline 2011 & 4.7683 & 30 & 986 & 0.188222 & 2012-2011 & 26 & 72.22 & 18.75 & 0.034239 & 0 \\
\hline 2012 & 3.4875 & 32 & 1054 & 0.136088 & 2013-2012 & 24 & 63.16 & 20 & 0.059215 & 0 \\
\hline 2013 & 4.8604 & 30 & 1305 & 0.247114 & 2014-2013 & 22 & 57.89 & 26.67 & 0.136545 & 0 \\
\hline 2014 & 3.4689 & 30 & 1334 & 0.11586 & 2015-2014 & 22 & 57.89 & 26.67 & -0.03983 & 100 \\
\hline 2015 & 3.3618 & 30 & 1218 & 0.132887 & Mean & 23.92 & 60.02 & 25.29 & 0.0526 & 0 \\
\hline
\end{tabular}

† DFe, degrees of freedom of the error.

and location effects, this methodology can be inefficient and inferior compared with the linear mixed models and could lead to overestimated or underestimated results.

The genetic gain results obtained using the Vencovsky cultivar substitution method should be interpreted with caution, especially when sequential years show highly contrasting behavior. For example, the conditions in one year may be favorable for the crop, but those of the next year may be highly detrimental for normal crop development, and vice versa. In the first case, a highly positive genetic gain will be obtained and in the second case a highly negative genetic gain. This occurred in the report by Follmann et al. (2017), where the genetic gain was negative in the biennia 2007-2006, 2010-2009, and

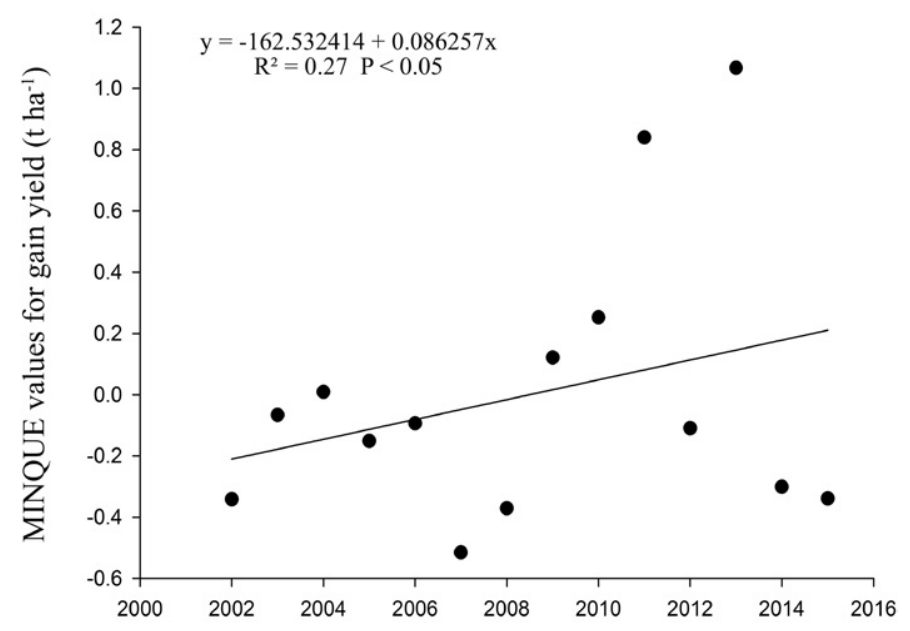

Years

Fig. 2. Effect of year of conduction of the trials on the increment of grain yield for spring wheat in Brazil. MINQUE, minimum norm quadratic unbiased estimation.
2011-2010 for Region 1. The most pronounced event was observed in two consecutive biennia for Region 1. In 2007-2006, the genetic gain was $-76.07 \mathrm{~kg} \mathrm{ha}^{-1}$, whereas it was $87.87 \mathrm{~kg} \mathrm{ha}^{-1}$ in 2008-2007. This indicated that a gain of $163.94 \mathrm{~kg} \mathrm{ha}^{-1}$ had occurred between these biennia. It is more plausible that these results were due to the environmental effect and not genetic gain. However, the linear mixed model methodology, where genetic effects are isolated, allows researchers to measure the genetic gain in both favorable and unfavorable years. In addition, when homogeneous wheat cultivation regions in Brazil were considered, Follmann et al. (2017) found that there was a genetic gain of $4.38 \% \mathrm{yr}^{-1}$ for Region 2. In this study, the most extreme examples occurred in the 2003-2002 and 2014-2013 biennia, when there were genetic gains of 206 and $136 \mathrm{~kg} \mathrm{ha}^{-1}$, respectively. Gains of these sizes could be overestimated and are not frequently reported, which indicates that the cultivar substitution methodology may not be reliable when it is used to analyze MET datasets.

\section{Achieving Genetic Gains and the Way Forward}

Among the 126 evaluated cultivars, some can be considered as key cultivars contributing to the genetic gain in spring wheat in Brazil: BR 23 (1987), BRS 177 (1999), Fundacep 30 (1999), Onix (2001), Quartzo (2007), and TBIO Toruk (2014). These cultivars were present in many years of evaluation, exception for TBIO Toruk released in 2014. These cultivars are parents of many other cultivars due their good agronomic performance and industrial quality: BR 23 is a parent of BRS Guabiju, BRS Louro, and BRS 208; BRS 177 is a parent of Campeiro, CD 
123, and TEC Triunfo; Fundacep 30 is a parent of LG Oro, Estrela Atria, TBIO Sinuelo, and TEC 10; Onix is a parent of Ametista, CD 1440, CD 1550, Esporao, Estrela Atria, FPS Nitron, Jadeíte 11, Mirante, Quartzo, TBIO Seleto, TBIO SINUELO, TBIO Tibagi, and TEC Triunfo; Quartzo is a parent of TBIO Iguacu, TBIO Itaipu, TBIO Sintonia, TBIO Sinuelo, TBIO Toruk, and TBIO Celebra; and TBIO Toruk is a parent of TBIO Sonic, a cultivar released in 2017.

The genetic gain obtained for the wheat crop in Brazil can be explained by the increase in traits that were not directly targeted by selection. The increase in GY was largely associated with harvest index, number of grains per square meter, biomass accumulation performance, and reduced plant height (Rodrigues et al., 2007; Beche et al., 2014b). Furthermore, plant breeding indirectly improved the postanthesis chlorophyll content, pre- and postanthesis stomatal conductance, and the pre- and postanthesis photosynthetic rate (Beche et al., 2014b). Further GY improvements in Brazilian wheat, and consequently in genetic gains, may be achieved by modeling plant morphology, physiology, and phenology. Beche et al. (2014b) indicated that increased photosynthetic capacity, optimized biomass production, and maintained lodging resistance are key traits that could be used to develop more productive cultivars.

The extraction and utilization capacity of the nutrients supplied to the plants is measured in relation to the nutrient use efficiency (Baligar and Fageria, 2015). Nitrogen use efficiency (NUE) results for modern Brazilian wheat cultivars show that they use $\mathrm{N}$ more efficiently and are more tolerant of lower $\mathrm{N}$ rates than older cultivars. Furthermore, $\mathrm{N}$ uptake and utilization efficiencies are positively associated with NUE (Beche et al., 2014a). When different N rates are applied, $\mathrm{N}$ remobilization efficiency was shown to be the main NUE component under both low and high $\mathrm{N}$ fertilization conditions (Todeschini et al., 2016). Wheat breeding programs should prioritize the selection of genotypes with higher $\mathrm{N}$ uptake, remobilization, and utilization efficiencies if cultivars that have better NUE are to be developed (Beche et al., 2014a).

The improvement in wheat GY potential across Brazil may also be related to changes in growth and developmental phases. Modern cultivars have maintained the length of the period from seedling emergence to physiological maturity, but have reduced the period between seedling emergence and anthesis. Therefore, they have a longer grain-filling period. Specifically, Brazilian breeding programs have reduced the time to anthesis mainly by shortening the seedling emergence to double ridge and double ridge to terminal spikelet phases, whereas simultaneously the terminal spikelet to anthesis and anthesis to physiological maturity phases have been prolonged (Rodrigues et al., 2007; Beche et al., 2014b, 2018).

\section{Yield Gap and Genetic Gain Stagnation in Brazilian Wheat Crops}

A positive and significant linear regression was obtained for the genetic gain between 1984 and 2014, which indicated that there was no genetic gain stagnation in Brazilian wheat after the 2000s. A possible explanation for this result is the creation of private wheat breeding companies in Brazil and the consequent increase in competition among wheat breeding companies. Private companies started their activities after the approval in Brazil of the Law of Protection of Cultivars in 1997. Our results contradict Beche et al. (2014b), who identified stagnation in genetic gain after the 2000s in Brazil. Several countries and several producing regions have reported genetic gain stagnation in wheat (Brisson et al., 2010; Grassini et al., 2013). This stagnation has been mainly observed in regions where the crop had high production means (Brisson et al., 2010; Petersen et al., 2010; Grassini et al., 2013), which led to the formation of upper plateaus (i.e., stagnation occurs after a period of linear increases in the genetic gain; Grassini et al., 2013). The results reported by Beche et al. (2014b) showed that the stagnation of wheat genetic gain in Brazil was affected by an upper plateau. Grassini et al. (2013) reported that upper plateaus occurred in areas that, in total, represented 33\% of global rice production and $27 \%$ of global wheat production.

The main environmental factors that contribute to the increase in GY across Brazil are the no-tillage crop system and the subsequent improvement in the chemical, physical, and biological quality of the soils, use of chemical fertilizers (especially $\mathrm{N}, \mathrm{P}$, and $\mathrm{K}$ ), soil $\mathrm{pH}$ correction, use of fungicides and insecticides, and so on.

The reasons of the yield gap between wheat crops in Brazil are complex. Climatic and economic aspects can be cited as the main reasons. Climatic aspects are related to temperature and hydrological regime, and their indirect effects on the occurrence of diseases and preharvest sprouting. The economic aspects are related to the technological level applied to the wheat crop. They are related to production costs, especially fertilizers, fungicides, and insecticides, and the uncertainty about sale prices. The climate factors can also include the effects of the climatic events, such as El Niño and La Nina, which affect the hydrological regime. In the southern region of Brazil, El Niño events cause increased precipitation and higher temperatures. In contrast, intense La Niña events can produce severe droughts (Grimm and Tedeschi, 2009; Abelen et al., 2015; Penalba and Rivera, 2016).

Diseases have a considerable impact on wheat in Brazil and are one of the most important causes of the yield gap. The most important diseases in Brazil are Fusarium head blight (Fusarium graminearum Schwab), leaf spotting diseases, and wheat blast (Pyricularia oryzae Cavara), which have the potential to cause yield losses of up to 70\% (Kohli and de Ackermann, 2013; Singh et 
al., 2016). Wheat blast, or brusone, is currently considered to be the main obstacle to the expansion of wheat cropping in the Brazilian Cerrado areas (Goulart et al., 2007; Maciel et al., 2014).

Preharvest sprouting is very common in Brazil and is caused by rainfall and high temperatures during ripening. This condition can lead to significant grain damage (Baranzelli et al., 2018). Damaged grains reduce industrial quality and the hectoliter mass. Hectoliter mass and GY are the two variables that are used to remunerate farmers for wheat production in Brazil.

The genetic gains in Brazil between 1985 and 2014 indicated that the breeding programs efficiently improved wheat crop yields. However, these gains were not sufficient to achieve the output that research has indicated is necessary to reach the production demand predicted for 2050. Furthermore, in Brazil, breeding programs also have the challenge of leading the country to self-sufficiency in wheat production.

\section{CONCLUSIONS}

The results of the present study revealed a genetic gain for spring wheat over the last $30 \mathrm{yr}$ in Brazil of $33.9 \mathrm{~kg} \mathrm{ha}^{-1}$ $\mathrm{yr}^{-1}$, which represents an increase of $1.28 \% \mathrm{yr}^{-1}$, indicating that the breeding programs efficiently improved wheat crop yields. Furthermore, there is no evidence that wheat genetic gains stagnated in Brazil at the beginning of the 21st century. Our findings demonstrate that genetic gains obtained for wheat in Brazil are not sufficient to achieve the output that research has indicated as necessary to reach the wheat production demand predicted for 2050. Brazilian wheat breeding programs also have the challenge of leading the country to selfsufficiency in wheat production.

\section{Supplemental Material}

Supplemental material is available online for this article.

\section{Conflict of Interest}

The authors declare that there is no conflict of interest.

\section{Acknowledgments}

We acknowledge Coordenação de Aperfeiçoamento de Pessoal de Nível Superior (CAPES) for granting the masters and doctoral scholarships. L.G. Woyann received a CAPES/Social Demand (CAPES/DS) scholarship and Doctorate Sandwich Abroad Program (CAPES/PDSE) scholarship (Process no. 88881.135500/2016-01).

\section{References}

Abelen, S., F. Seitz, R. Abarca-del-Rio, and A. Güntner. 2015. Droughts and floods in the La Plata basin in soil moisture data and GRACE. Remote Sens. 7:7324-7349. doi:10.3390/ rs70607324
Aisawi, K.A.B., M.P. Reynolds, R.P. Singh, and M.J. Foulkes. 2015. The physiological basis of the genetic progress in yield potential of CIMMYT spring wheat cultivars from 1966 to 2009. Crop Sci. 55:1749-1764. doi:10.2135/cropsci2014.09.0601

Baligar, V.C., and N.K. Fageria. 2015. Nutrient use efficiency in plants: An overview. In: A. Rakshit, et al., editors, Nutrient use efficiency: From basics to advances. Springer, New Delhi. doi:10.1007/978-81-322-2169-2_1

Baranzelli, J., D.H. Kringel, R. Colussi, F.F. Paiva, B.C. Aranha, M.Z. de Miranda, et al. 2018. Changes in enzymatic activity, technological quality and gamma-aminobutyric acid (GABA) content of wheat flour as affected by germination. LWT 90:483-490. doi:10.1016/j.lwt.2017.12.070

Beche, E., G. Benin, E. Bornhofen, S.C. Dalló, L.H.S. Sassi, and R.D. Oliveira. 2014a. Nitrogen use efficiency of pioneer and modern wheat cultivars. Pesqi. Agropecu. Bras. 49:948-957. doi:10.1590/S0100-204X2014001200005

Beche, E., G. Benin, C.L. da Silva, L.B. Munaro, and J.A. Marchese. 2014b. Genetic gain in yield and changes associated with physiological traits in Brazilian wheat during the 20th century. Eur. J. Agron. 61:49-59. doi:10.1016/j.eja.2014.08.005

Beche, E., C.L. da Silva, M.H. Todeschini, A.S. Milioli, G. Benin, and J.A. Marchese. 2018. Improvement in Brazilian wheat breeding: Changes in developmental phases and ecophysiological traits. Euphytica 214:56. doi:10.1007/s10681-018-2134-2

Bell, M.A., R.A. Fischer, D. Byerlee, and K. Sayre. 1995. Genetic and agronomic contributions to yield gains: A case study for wheat. Field Crops Res. 44:55-65. doi:10.1016/03784290(95)00049-6

Breseghello, F., O.P. de Morais, P.V. Pinheiro, A.C.S. Silva, E. da Maia de Castro, É.P. Guimarães, et al. 2011. Results of 25 years of upland rice breeding in Brazil. Crop Sci. 51:914-923. doi:10.2135/cropsci2010.06.0325

Brisson, N., P. Gate, D. Gouache, G. Charmet, F.X. Oury, and F. Huard. 2010. Why are wheat yields stagnating in Europe. A comprehensive data analysis for France. Field Crops Res. 119:201-212. doi:10.1016/j.fcr.2010.07.012

Burgueño, J., J. Crossa, J.M. Cotes, F. San Vicente, and B. Das. 2011. Prediction assessment of linear mixed models for multienvironment trials. Crop Sci. 51:944-954. doi:10.2135/cropsci2010.07.0403

Cargnin, A., M.A. Souza, V. Fronza, and C.M. Fogaça. 2009. Genetic and environmental contributions to increased wheat yield in Minas Gerais, Brazil. Sci. Agric. 66(3). doi:10.1590/ S0103-90162009000300006

Cassman, K.G., A. Dobermann, D.T. Walters, and H. Yang. 2003. Meeting cereal demand while protecting natural resources and improving environmental quality. Annu. Rev. Environ. Resour. 28:315-358. doi:10.1146/annurev. energy.28.040202.122858

CONAB. 2017. Séries históricas trigo. Comp. Nac. Abastecimento. http://www.conab.gov.br/OlalaCMS/uploads/arquivos/17_12_12_16_43_12_trigoseriehist.xls (accessed 26 Dec. 2017).

de la Vega, A.J., I.H. DeLacy, and S.C. Chapman. 2007. Progress over 20 years of sunflower breeding in central Argentina. Field Crops Res. 100:61-72. doi:10.1016/j.fcr.2006.05.012

Follmann, D.N., F.A. Cargnelutti, A.D. Lúcio, V.Q. de Souza, M. Caraffa, and C.A. Wartha. 2017. Genetic progress in homogeneous regions of wheat cultivation in Rio Grande do Sul State, Brazil. Genet. Mol. Res. 16(1). doi:10.4238/gmr16019517 
Gibbs, H.K., A.S. Ruesch, F. Achard, M.K. Clayton, P. Holmgren, N. Ramankutty, and J.A. Foley. 2010. Tropical forests were the primary sources of new agricultural land in the 1980s and 1990s. Proc. Natl. Acad. Sci. USA 107:16732-16737. doi:10.1073/pnas.0910275107

Godfray, H.C.J., J.R. Beddington, I.R. Crute, L. Haddad, D. Lawrence, J.F. Muir, et al. 2010. Food security: The challenge of feeding 9 billion people. Science 327:812-818. doi:10.1126/ science. 1185383

Goulart, A.C.P., P.G. Sousa, and A.S. Urashima. 2007. Damages in wheat caused by infection of Pyricularia grisea. Summa Phytopathol. 33:358-363. doi:10.1590/S0100-54052007000400007

Grassini, P., K.M. Eskridge, and K.G. Cassman. 2013. Distinguishing between yield advances and yield plateaus in historical crop production trends. Nat. Commun. 4:2918. doi:10.1038/ ncomms3918

Graybosch, R., H.E. Bockelman, K.A. Garland-Campbell, D.F. Garvin, and T. Regassa. 2014. Wheat. In: J. Specht and B. Carver, editors, Yield gains in major U.S. field crops. CSSA Spec. Publ. 33. ASA, CSSA, and SSSA, Madison, WI. p. 459488, doi:10.2135/cssaspecpub33.c16.

Graybosch, R.A., and C.J. Peterson. 2010. Genetic improvement in winter wheat yields in the Great Plains of North America, 19592008. Crop Sci. 50:1882-1890. doi:10.2135/cropsci2009.11.0685

Grimm, A.M., and R.G. Tedeschi. 2009. ENSO and extreme rainfall events in South America. J. Clim. 22:1589-1609. doi:10.1175/2008JCLI2429.1

Hawkins, E., T.E. Fricker, A.J. Challinor, C.A. Ferro, C.K. Ho, and T.M. Osborne. 2013. Increasing influence of heat stress on French maize yields from the 1960s to the 2030s. Glob. Change Biol. 19:937-947. doi:10.1111/gcb.12069

Kohli, M.M., and M.D. de Ackermann. 2013. Resistance to Fusarium head blight in South American wheat germplasm. In: T.M. Alconanda Magliano and S.N. Chulze, editors, Fusarium head blight in Latin America. Springer, New York. p. 263-297. doi:10.1007/978-94-007-7091-1_16

Laidig, F., H.P. Piepho, T. Drobek, and U. Meyer. 2014. Genetic and non-genetic long-term trends of 12 different crops in German official variety performance trials and on-farm yield trends. Theor. Appl. Genet. 127:2599-2617. doi:10.1007/ s00122-014-2402-z

Lal, R. 2015. Restoring soil quality to mitigate soil degradation. Sustainability 7:5875-5895. doi:10.3390/su7055875

Li, X., N. Liu, L. You, X. Ke, H. Liu, M. Huang, and S.R. Waddington. 2016. Patterns of cereal yield growth across China from 1980 to 2010 and their implications for food production and food security. PLoS One 11:e0159061. doi:10.1371/journal.pone.0159061

Lo Valvo, P.J., D.J. Miralles, and R.A. Serrago. 2018. Genetic progress in Argentine bread wheat varieties released between 1918 and 2011: Changes in physiological and numerical yield components. Field Crops Res. 221:314-321. doi:10.1016/j.fcr.2017.08.014

Lopez-Cruz, M., J. Crossa, D. Bonnett, S. Dreisigacker, J. Poland, J.L. Jannink, et al. 2015. Increased prediction accuracy in wheat breeding trials using a marker $\times$ environment interaction genomic selection model. G3: Genes, Genomes, Genet. 5:569-582. doi:10.1534/g3.114.016097

Maciel, J.L.N., P.C. Ceresini, V.L. Castroagudin, M. Zala, G.H. Kema, and B.A. McDonald. 2014. Population structure and pathotype diversity of the wheat blast pathogen Magnaporthe oryzae 25 years after its emergence in Brazil. Phytopathology 104:95-107. doi:10.1094/PHYTO-11-12-0294-R
Matei, G., G. Benin, L.G. Woyann, S.C. Dalló, A.S. Milioli, and A.D. Zdziarski. 2017. Agronomic performance of modern soybean cultivars in multi-environment trials. Pesqi. Agropecu. Bras. 52:500-511. doi:10.1590/s0100-204x2017000700004

Matus, I., M. Mellado, M. Pinares, R. Madariaga, and A. del Pozo. 2012. Genetic progress in winter wheat cultivars released in Chile from 1920 to 2000. Chil. J. Agric. Res. 72:303-308. doi:10.4067/S0718-58392012000300001

Morgounov, A., V. Zykin, I. Belan, L. Roseeva, Y. Zelenskiy, H.F. Gomez-Becerra, et al. 2010. Genetic gains for grain yield in high latitude spring wheat grown in western Siberia in 1900-2008. Field Crops Res. 117:101-112. doi:10.1016/j. fcr.2010.02.001

Penalba, O.C., and J.A. Rivera. 2016. Precipitation response to El Niño/La Niña events in southern South America: Emphasis in regional drought occurrences. Adv. Geosci. 42:1-14. doi:10.5194/adgeo-42-1-2016

Peng, S., K.G. Cassman, S.S. Virmani, J. Sheehy, and G.S. Khush. 1999. Yield potential trends of tropical rice since the release of IR 8 and the challenge of increasing rice yield potential. Crop Sci. 39:1552-1559. doi:10.2135/cropsci1999.3961552x

Peng, S., J. Huang, K.G. Cassman, R.C. Laza, R.M. Visperas, and G.S. Khush. 2010. The importance of maintenance breeding: A case study of the first miracle rice variety-IR 8. Field Crops Res. 119:342-347. doi:10.1016/j.fcr.2010.08.003

Petersen, J., M. Haastrup, L. Knudsen, and J.E. Olesen. 2010. Causes of yield stagnation in winter wheat in Denmark. DJF Rep. Plant Sci. 147. Aarhus Univ. https://pure.au.dk/ ws/files/34119017/DJF_Rap.Mark147_internet.pdf (accessed January 2018).

Piepho, H.-P., and J. Möhring. 2005. Best linear unbiased prediction of cultivar effects for subdivided target regions. Crop Sci. 45:1151-1159. doi:10.2135/cropsci2004.0398

Piepho, H.-P., and J. Möhring. 2006. Selection in cultivar trials: Is it ignorable? Crop Sci. 46:192-201. doi:10.2135/cropsci2005.04-0038

Qin, X., F. Zhang, C. Liu, H. Yu, B. Cao, S. Tian, et al. 2015. Wheat yield improvements in China: Past trends and future directions. Field Crops Res. 177:117-124. doi:10.1016/j.fcr.2015.03.013

R Development Core Team. 2017. R: A language and environment for statistical computing. R Found. Stat. Comput., Vienna.

Rao, C.R. 1971. Estimation of variance and covariance components: MINQUE theory. J. Multivariate Anal. 1:257-275. doi:10.1016/0047-259X(71)90001-7

Ray, D.K., N.D. Mueller, P.C. West, and J.A. Foley. 2013. Yield trends are insufficient to double global crop production by 2050. PLoS One 8:e66428. doi:10.1371/journal.pone.0066428

Rodrigues, O., J.C.B. Lhamby, A.D. Didonet, and J.A. Marchese. 2007. Fifty years of wheat breeding in southern Brazil: Yield improvement and associated changes. Pesqi. Agropecu. Bras. 42:817-825. doi:10.1590/S0100-204X2007000600008

RStudio Team. 2016. RStudio: Integrated development for R. RStudio, Boston, MA.

Sanchez-Garcia, M., C. Royo, N. Aparicio, J.A. Martín-Sánchez, and F. Álvaro. 2013. Genetic improvement of bread wheat yield and associated traits in Spain during the 20th century. J. Agric. Sci. 151:105-118. doi:10.1017/S0021859612000330

Singh, R.P., P.K. Singh, J. Rutkoski, D.P. Hodson, X. He, L.N. Jørgensen, et al. 2016. Disease impact on wheat yield potential and prospects of genetic control. Annu. Rev. Phytopathol. 54:303-322. doi:10.1146/annurev-phyto-080615-095835 
So, Y., and J. Edwards. 2011. Predictive ability assessment of linear mixed models in multienvironment trials in corn. Crop Sci. 51:542-552. doi:10.2135/cropsci2010.06.0338

Storck, L., D.A. Bisognin, and A. Cargnelutti Filho. 2005. Ganho genético decorrente da substituição anual de cultivares de milho. Pesqi. Agropecu. Bras. 40:881-886. doi:10.1590/ S0100-204X2005000900007

Systat Software. 2008. SigmaPlot 11.0 for Windows. Systat Software, San Jose, CA.

Tweeten, L., and S.R. Thompson. 2008. Long-term agricultural output supply-demand balance and real farm and food prices. Working Paper AEDE-WP 0044-08. Ohio State Univ., Columbus, $\mathrm{OH}$.

Todeschini, M.H., A.S. Milioli, D.M. Trevizan, E. Bornhofen, T. Finatto, L. Storck, and G. Benin. 2016. Nitrogen use efficiency in modern wheat cultivars. Bragantia 75:351-361. doi:10.1590/1678-4499.385

Vencovsky, R., A.R. Morais, J.C. Garcia, and N.M. Teixeira. 1988. Progresso genético em vinte anos de melhoramento do milho no Brasil. In: 16th Congresso Nacional de Milho e Sorgo, Anais, Sete Lagoas. Embrapa-CNPMS, Belo Horizonte, MG. Brazil. p. 300-307.
Wu, J. 2014. minque: A R package for linear mixed model analyses. R Package Version 1.1. Comprehensive R Arch. Network, Vienna.

Wu, J., J.C. McCarty, and J.N. Jenkins. 2010. Cotton chromosome substitution lines crossed with cultivars: Genetic model evaluation and seed trait analyses. Theor. Appl. Genet. 120:14731483. doi:10.1007/s00122-010-1269-x

Wu, W., C. Li, B. Ma, F. Shah, Y. Liu, and Y. Liao. 2014. Genetic progress in wheat yield and associated traits in China since 1945 and future prospects. Euphytica 196:155-168. doi:10.1007/s10681-013-1033-9

Xiao, D., and F. Tao. 2014. Contributions of cultivars, management and climate change to winter wheat yield in the North China Plain in the past three decades. Eur. J. Agron. 52:112122. doi:10.1016/j.eja.2013.09.020

Xu, Y., P. Li, C. Zou, Y. Lu, C. Xie, X. Zhang, et al. 2017. Enhancing genetic gain in the era of molecular breeding. J. Exp. Bot. 68:2641-2666. doi:10.1093/jxb/erx135

Yan, W. 2015. Mega-environment analysis and test location evaluation based on unbalanced multiyear data. Crop Sci. 55:113122. doi:10.2135/cropsci2014.03.0203 